\title{
Vulnerability of crop production to climatic variability in a water stress area of north-west region of Bangladesh: a case study in the Sapahar Upazila under Naogaon District
}

\author{
Abdullah-Al-Masud", Ayesha Khatun Liza and Dr. Abul Kalam Azad \\ Environmental Science Discipline, Khulna University, Khulna-9208, Bangladesh \\ *Corresponding Author
}

\begin{abstract}
Agricultural production in north-west part of Bangladesh is highly vulnerable to climate variability. Thus the present study has been conducted in Sapahar Upazila of Naogaon District, Bangladesh to explore the impact of climatic variations on crop yields using the climate data analysis and farm surveys. The local knowledge and resource based adaptation techniques adopted by the farmers has been also evaluated. To explore the vulnerability, the trend analysis of temperature, rainfall and relative humidity of the study area and its relation with the crop production has been examined. Then these statistical data has been compare with the farmer's views. Farmer's perception has been also assessed through semi-structured questionnaire by using purposive sampling technique. The study result shows that, the temperature and relative humidity of the region are increasing whereas the rainfall is decreasing in a sharp rate. The lower and irregular rainfall has increased the pressure on the ground water based supplementary irrigation which is one the main reasons for the depletion of ground water level gradually as the production is strongly correlated with the ground water level and irrigation development. In multiple regression analysis with crop yield and climatic and water resources variables, it is revealed that, 92, 42, 90, and $82 \%$ of the variance in aman, aus, boro and wheat respectively, can be explained by the present study. Majority of the farmer's said that climatic variation has hampered the production which responsible for the more requirement of the agriculture input. Local farmers responded that different climatic variation including temperature increase, monsoonal change, erratic rainfall, lower rainfall in the winter, prolonged dry spell etc which are also observed in the trend analysis of the climatic factors. Farmers also identified different consequences due to the climatic variation including lower production, delay of transplantation, required extensive irrigation, higher pest and viral attack etc. which ultimately reduce economic return. Local farmer's have adopted different coping mechanism to minimize the impact of climatic variation on crop production including change of transplantation time, cropping pattern change, digging small pond besides the land, selection of short duration species etc. The study concluded that the impact of climatic variations on crop yields in the study area is substantial especially under water scarcity conditions. The need to enhance farmer's adaptive strategies must be emphasized.
\end{abstract}

Keywords: adaptation, climatic variability, farmer's perception, vulnerability, water stress.

\section{Introduction}

The economy of Bangladesh is predominantly agricultural. Since the birth of Bangladesh, the country has achieved an incredible growth in food production due to substantial cropping intensification, introduction of high yielding crop varieties, expansion of irrigated areas and increased use of chemical fertilizers. However Bangladesh is presently facing a serious challenge in agricultural production to feed the growing population in the context of shrinking agricultural land and impact of climatic variability. Global warming induced changes in temperature and rainfall are already evident in many parts of the world, as well as in our country (Ahmed and Alam 1999). Hazards like floods, droughts, cyclones and others, which are aggravated by climate change and its variability being experienced more frequently in Bangladesh than ever before. Uncertainty of rainfall and uneven temporal and spatial distribution in one hand, creating flooding and of the other hand longer dry spells evoking droughty conditions (Lai, et. al. 1998).

The Fourth Assessment Report of the Intergovernmental Panel on Climate Change (IPCC) points out that freshwater availability in Asia is projected to decrease due to climate change. By the middle of the 21st century, annual average river runoff and water availability are projected to decrease by $10-30 \%$ relative to 1900-70 over some dry regions at mid-latitudes and in the dry tropics (IPCC 2007). It is also prognosticated that, under climate change scenario evapo-transpiration will increase significantly, especially during the postmonsoon and pre-monsoon seasons, in the backdrop of diminishing rainfall in winter and already erratic rainfall variability over time and space (Karim et al., 1998). As a consequence, severity of moisture stress, particularly in the north-western districts, will increase leading to drought conditions. An earlier estimate suggests that the 
area severely affected by drought in Rabi season could increase from $4000 \mathrm{~km}^{2}$ to $12000 \mathrm{~km}^{2}$ under severe climate change scenario (Huq et al. 1996).

As a result of climate change, every year Bangladesh experiences a dry period for seven months, from November to May, when rainfall is normally low. Apart from this, inadequate pre-monsoon showers, a delay in the onset of the rainy season or an early departure of the monsoon may create droughts in Bangladesh (Shafie $e t$ al. 2009). Adding together, ADB states that lower precipitation during the dry season under climate change has the potential to increase drought risk in Bangladesh (ADB, 2005). It is a recurrent phenomenon in some parts of the country, but the north-west region is mostly a drought-prone area because of high rainfall variability receiving much lower rainfall compared to the rest of the country thus this area is relatively dry. The average annual rainfall in this part is $1329 \mathrm{~mm}$ whereas in the north-east part the average annual rainfall is $4338 \mathrm{~mm}$ (Shahid and Behrawan, 2008). Nevertheless, drought can hit both drought-prone and non-drought prone areas of Bangladesh and it is being reported more in Rajshahi, Chapai Nawabganj, Naogaon, Rangpur, Bogura, Pabna, Dinajpur and Kustia Districts of Bangladesh because of the characteristics of moisture retention capacity and infiltration rate (Paul, 1995).

\section{Methodology of the study}

At first, the study topic has been conceptualized and then the objectives followed by the study area have been selected. The study has been carried out in two union of Sapahar Upazila named Sapahar and Tilna Union.

\subsection{Description of the study area}

The study area is located between $25^{\circ} 01$ and $25^{\circ} 13$ north latitudes and between $88^{\circ} 26$ and $88^{\circ} 38$ east latitudes. The Sapahar Upazila occupies an area of 244.49 sq. km (BBS, 2001) is bounded by West Bengal of India on the north and west, Porsha Upazila on the south, Patnitala Upazila on the east. Main River is Punarbhaba; Jaboi Beel is notable. The study area is mainly constituted by two major Physiography; Barind and Teesta Floodplain. The Barind area covers $74.6 \%$ of the Upazila (CEGIS \& FAO, 2006). It is mainly consists of wide flat terrace and valley areas. Barind area is generally 1 to 2 meter higher than the floodplain and relatively older deposits. Normally valley separates the trace areas, which helps in draining out the water naturally. High terrace and valley areas are free from flooding but lower areas are subjected to flooding in the monsoon season. Teesta floodplain (15.4\%) is mainly constituted by Highland and Beel area. The general topography of the study area is ranges from 15 to 50 meter (CEGIS \& FAO, 2006). The Barind area is mainly high comparatively than the other part of the flood plains. The western side of the study area is composed of flood plain soil, which is depressed area and inundates from average year flooding due to spillage of riverbanks.

The major soils of the study area are Clay-Clayey loam and Loam Clay-Clayey loam-Loam soil (98\%) dominates the area with a small portion of Sandy loam (2\%) soils (CEGIS \& FAO, 2006). The top and sub soil is generally Clay to Loam and substratum is dominantly Clay soil. The internal drainage characteristic of the soil is generally imperfectly drained i.e. water seepage from the soils at a slower rate and normally water does not stand on the surface for more than 15 days, but sopping wet in the rainy season. Surface water drains out during the month of mid-September to October, and land is paced for cultivation for Rabi crops.

The mean annual temperature is around $25^{\circ} \mathrm{C}$ and mean minimum and maximum temperature varies from (16-35 $)^{0} \mathrm{C}$. High temperature is generally observed in the month of April and May and lowest in the month of January. The recorded maximum highest temperature is observed as high as $44^{0} \mathrm{C}$ and as low as $4^{\circ} \mathrm{C}$ (CEGIS \& FAO, 2006). Trend pattern of temperature shows that the high temperature is increasing in the recent decades.
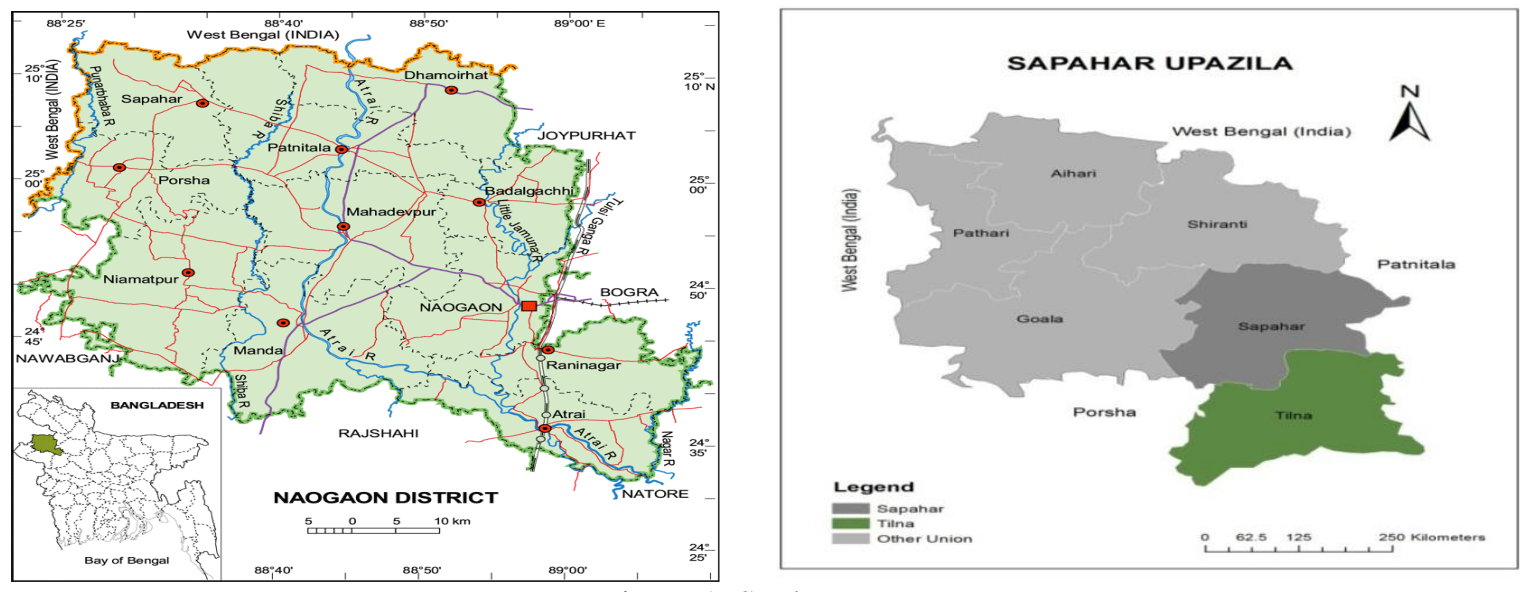

Figure 1: Study area 


\subsection{Data collection and processing}

Both primary and secondary data were collected to complete the present study. Primary data were collected from field observation, reconnaissance survey, questionnaire survey and key informants interviews during the January-May, 2012. Secondary data were collected from different sources. Before questionnaire survey, Reconnaissance Survey of the study site was done to assess the prevailing conditions at the site and issues to include in the study. Then a well-defined semi-structured questionnaire was prepared according to the objectives of the research and systematic random sampling technique has been applied as sampling procedure. On the basis of the Kothari, 2006 formula, 100 household is drawn as sample size from the total 800 household which is $10 \%$ of the total household at $95 \%$ confidence level. Meteorological data are collected through different organizations including BMD, BMDA, DAE of Naogaon etc. The collected data has been analyzed through some statistical software (SPSS, MS Excel etc.). Data of rainfall, temperature, relative humidity and ground water level were processed according to the seasonal variation to evaluate the climate variability accurately as much as possible. Average of month of respective data was calculated from the time series data.Then data were processed for the four following seasons such as:

$\checkmark \quad$ Monsoon: June, July, August (JJA)

$\checkmark \quad$ Post-Monsoon: September, October, November (SON)

$\checkmark \quad$ Winter: December, January, February (DJF)

$\checkmark \quad$ Pre-Monsoon: March, April, May (MAM)

The trend pattern was evaluated from the equation $y=m x+c$. Where $m$ impels the rate or trend value per year and last square value $\mathrm{R}^{2}$ reveals the significance number to fit with the trend line.

The ground water withdrawal for irrigation in the study area have been calculated on the basis of the number of tube well, their pumping rate, number of days used in year and hours in a day. From the DAE and field survey, pumping rate of STW was found to be 0.5 cusec and that of DTW 2 cusec. The calculation formula given below-

Irrigationwater, Mm3 $(S T W)=\frac{(\# \text { STW } \times 0.5 \text { cusec }) \times \frac{10 h r}{d a y} \times \frac{105 d}{y r} \times 0.02832 \mathrm{~m}^{3}}{10^{6}}$

\subsection{Trends of Climatic Variation}

\section{Result and Discussion}

\subsubsection{Trend of Temperature}

An overall increase in temperature is observed in the study area over the period of 1990-2011. However, the pattern of temperature trend is irregular. Fig. 2 reveals that the average temperature of the region is rising and the rate of trend is $0.030{ }^{\circ} \mathrm{C} / \mathrm{yr}$ with low fit $\mathrm{R}^{2} 0.36$.

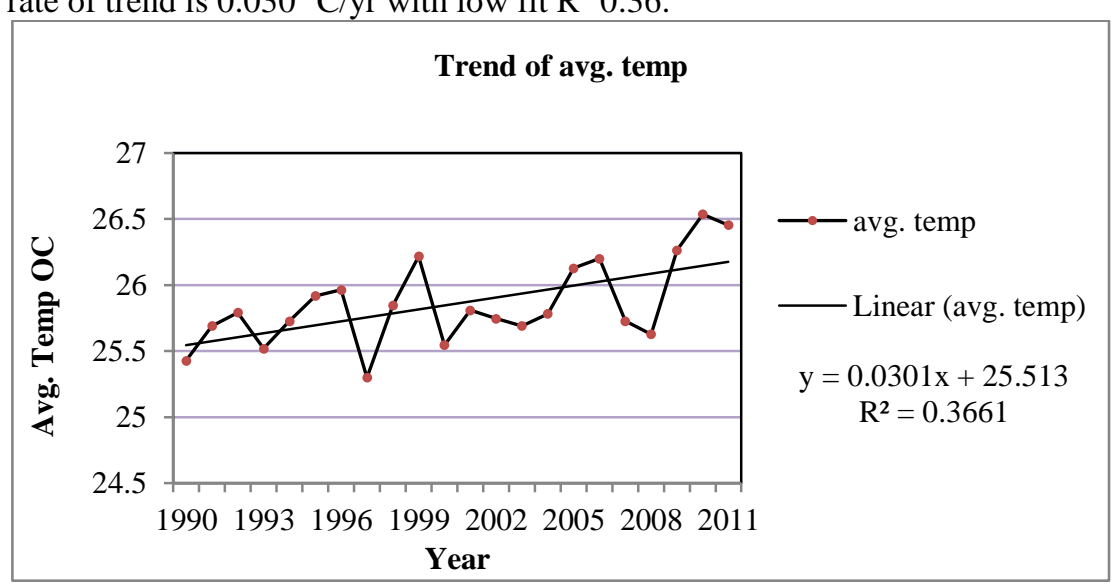

Figure 2: Trend of average temperature in the study area (Source: BMD, 2012)

In the study area, the temperature pattern of different season is also showing positive trend. The average temperature of pre-monsoon (DJF), monsoon (MAM), post-monsoon (JJA) and winter (SON) are reveals positive trend and the trend values are $0.057{ }^{\circ} \mathrm{C} / \mathrm{yr}, 0.029{ }^{\circ} \mathrm{C} / \mathrm{yr}, 0.024{ }^{\circ} \mathrm{C} / \mathrm{yr}$ and $0.028{ }^{\circ} \mathrm{C} / \mathrm{yr}$, respectively with respective $\mathrm{R}^{2}$ values are $0.1634,0.3006,0.1475$ and 0.3822 , respectively. 


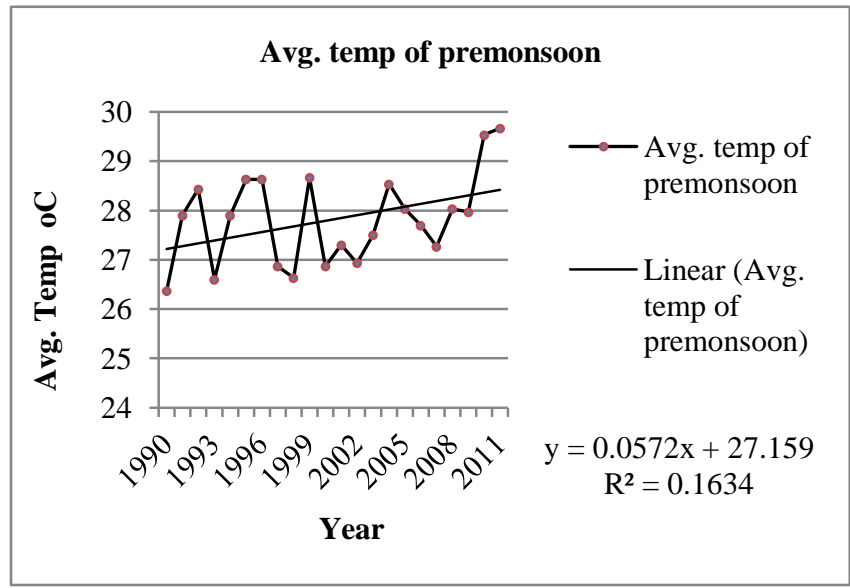

Figure 3: Trend of average temperature of pre-monsoon (Source: BMD, 2012)

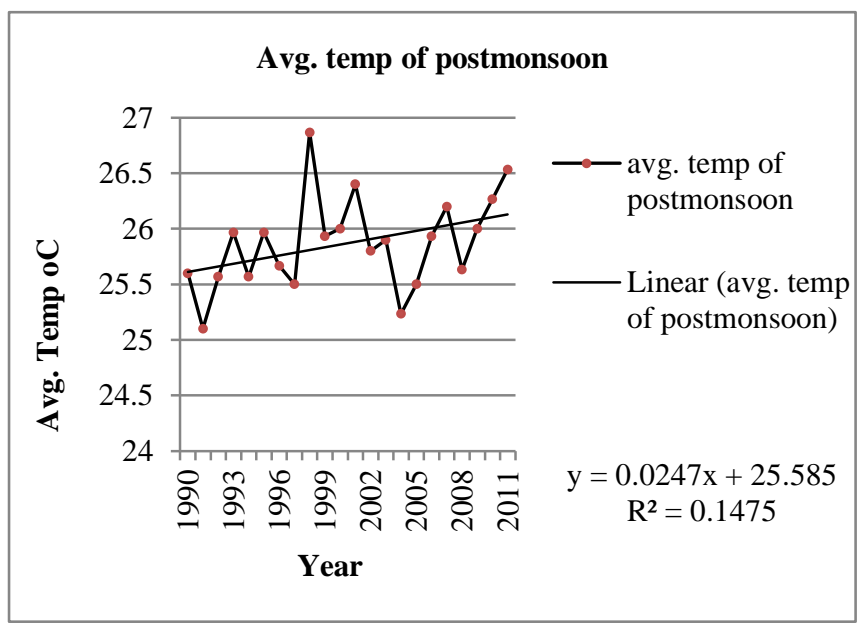

Figure 5: Trend of average temperature of post-monsoon (Source: BMD, 2012)

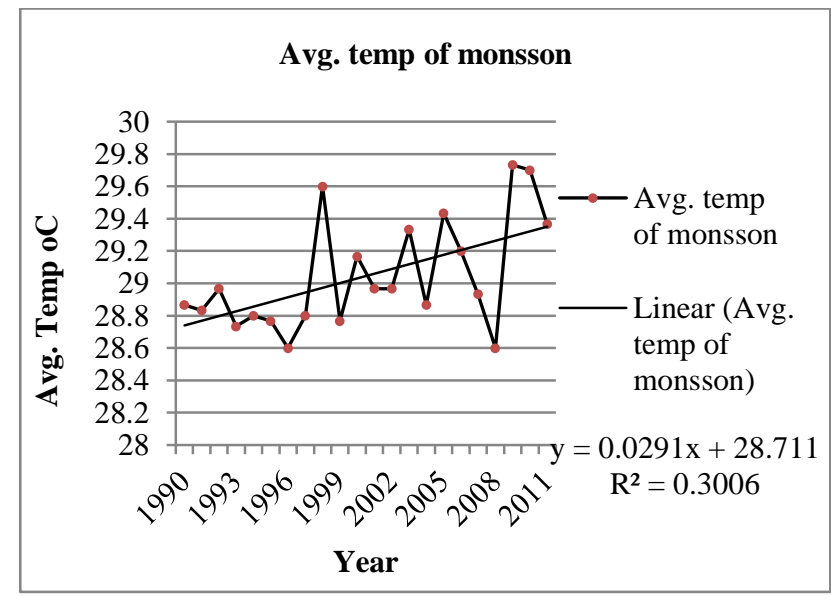

Figure 4: Trend of average temperature of monsoon (Source: BMD, 2012)

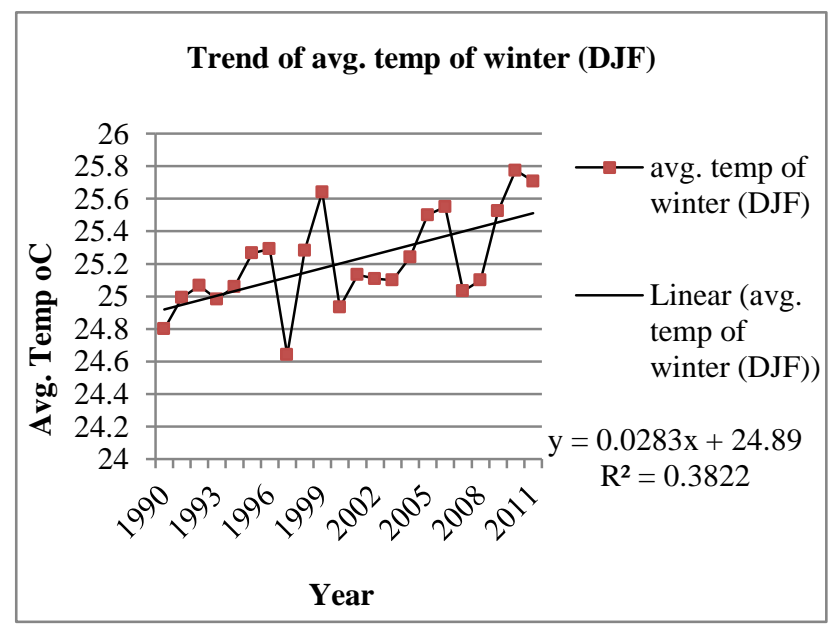

Figure 6: Trend of average temperature of winter (Source: BMD, 2012)

\subsubsection{Trend of Rainfall}

The study area is one of the most water scarce areas in Bangladesh as the total rainfall is very lower than the other parts of the country. Though the temperature trend in the study area showing a gradual increasing trend whereas the rainfall pattern decreasing gradually. In the last 10 years, the total rainfall of the study area is decreasing alarmingly and currently it's around $1000 \mathrm{~mm}-1100 \mathrm{~mm}$ in year which is very lower than the average rainfall $(1600 \mathrm{~mm})$ of the country (Banglapedia, 2006).

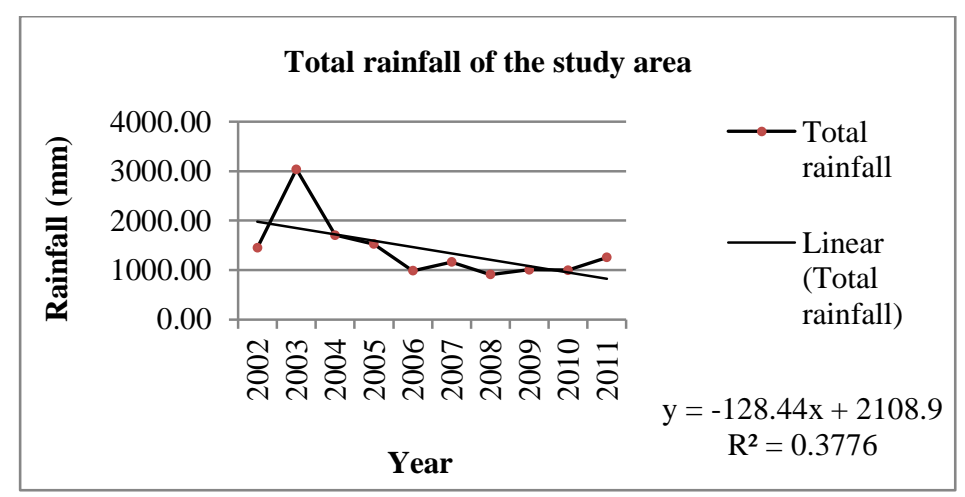

Figure 7: Total rainfall of the study area (Source: BMD and BMDA, 2012)

In different seasons, the rainfall pattern of the study area is also showing a negative trend. In the premonsoon the rainfall is very lower and it's decreasing gradually with a trend rate of $-13.51 \mathrm{~mm} / \mathrm{year}$ and with a 
lower fit $\mathrm{R}^{2}$ value of 0.1781 . This situation is responsible for hampering the preparation of the monsoonal crop specially the aman production.

In the monsoon time, the major portion of rainfall in the area is occurring but still it's showing a negative trend. The trend line is showing that, the rainfall in the month of June, July and August decreasing with the trend rate of $-81.80 \mathrm{~mm} /$ year which is very high and with a very lower fit of $\mathrm{R}^{2}$ value of 0.22 . In the postmonsoon, the rainfall is almost not occurring in the study area as it's decreasing drastically. The trend rate and $\mathrm{R}^{2}$ value of this season is $-32.45 \mathrm{~mm} / \mathrm{yr}$ and 0.40 , respectively.

In the winter season, the rainfall is almost absent in the study area and showing a negative trend. This situation is greatly hampering the winter crop production especially boro production as it's increasing the water requirement for the irrigation.

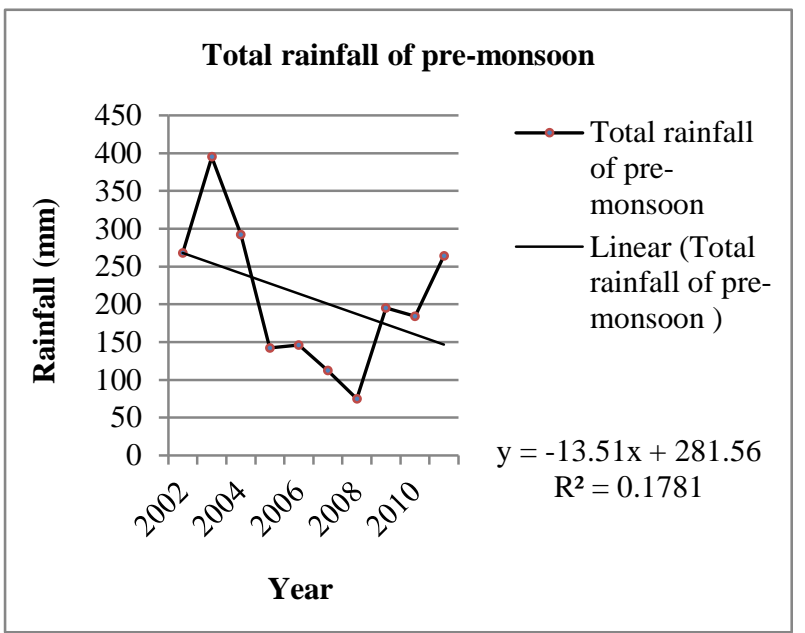

Figure 8: Total rainfall of pre-monsoon

(Source: BMD and BMDA, 2012)

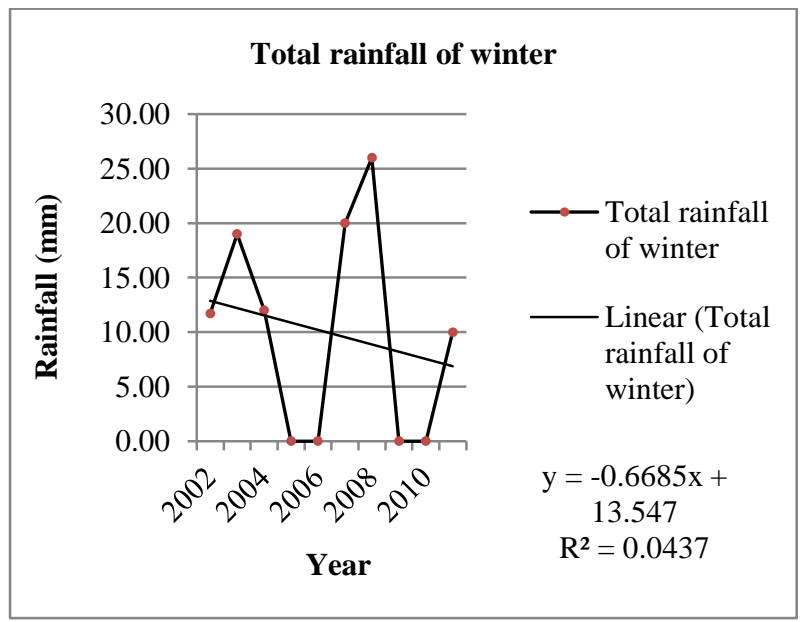

Figure 10: Total rainfall of post-monsoon

(Source: BMD and BMDA, 2012)

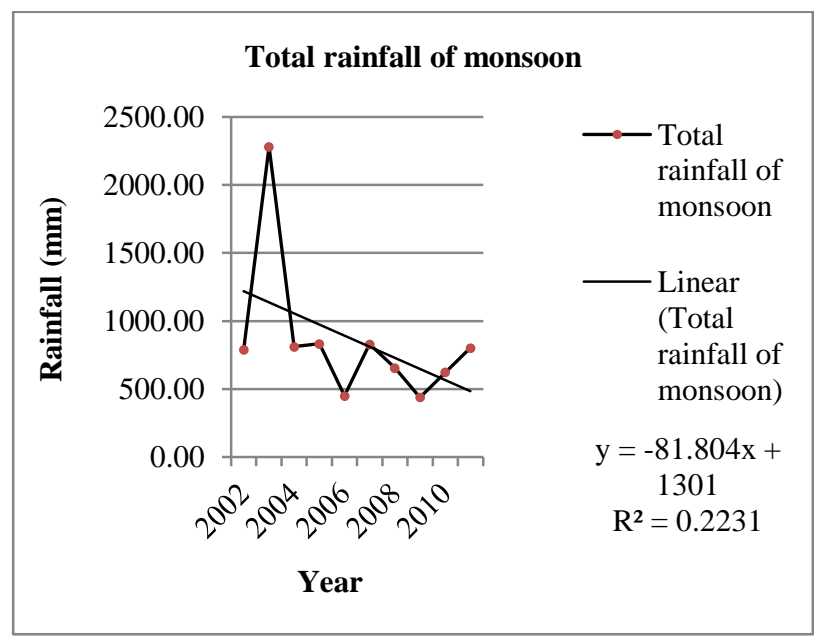

Figure 9: Total rainfall of monsoon (Source: BMD and BMDA, 2012)

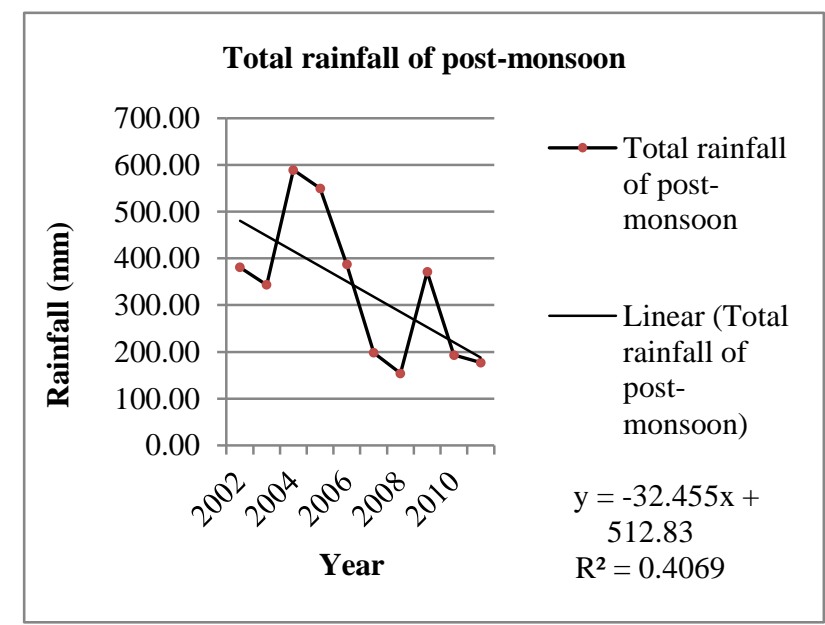

Figure 11: Total rainfall of winter

(Source: BMD and BMDA, 2012)

\subsubsection{Trend of Relative Humidity}

The average relative humidity of the study area is observed to rise at high rate during the period of 1995-2011. However, the trend of relative humidity is irregular. In Fig. 12 reveals that the average humidity of the area is rising and the rate of trend is $0.080 \%$ per year and with a low fit $\mathrm{R}^{2}$ value of 0.0866 . 


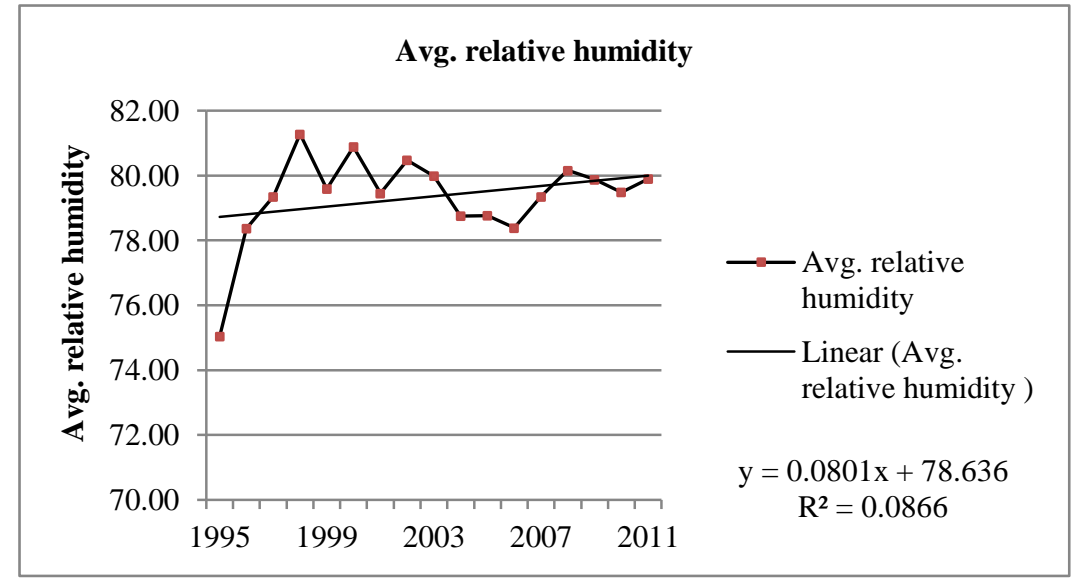

Figure 12: Average relative humidity of the study area (Source: BMD, 2012)

In the study area, the relative humidity pattern of winter (SON), pre-monsoon (DJF) and monsoon (MAM) are showing positive trend and the trend values are $0.150 \%$ per year, $0.171 \%$ per year and $0.014 \%$ per year, respectively with respective $\mathrm{R}^{2}$ values are $0.143,0.095$ and 0.004 , respectively. However, post-monsoon shows a negative trend and the trend value is $-0.016 \%$ per year and with very low $\mathrm{R}^{2}$ value of 0.0039 .

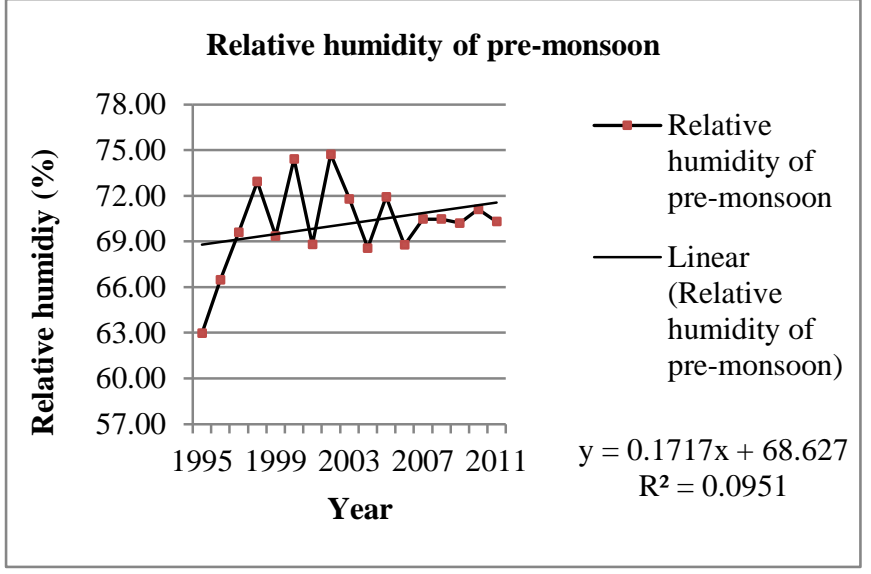

Figure 13: Relative humidity of pre-monsoon season (Source: BMD, 2012)

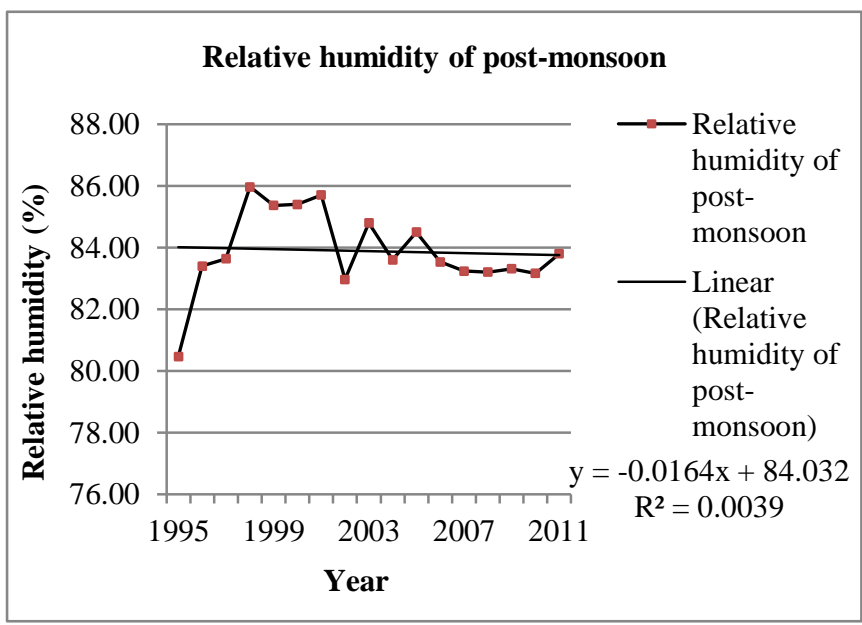

Figure 15: Relative humidity of post-monsoon season (Source: BMD, 2012)

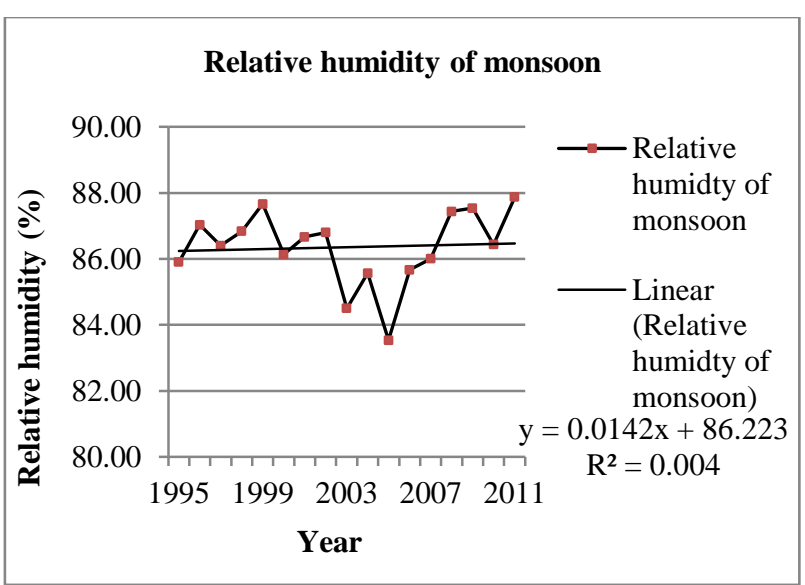

Figure 14: Relative humidity of monsoon season (Source: BMD, 2012)

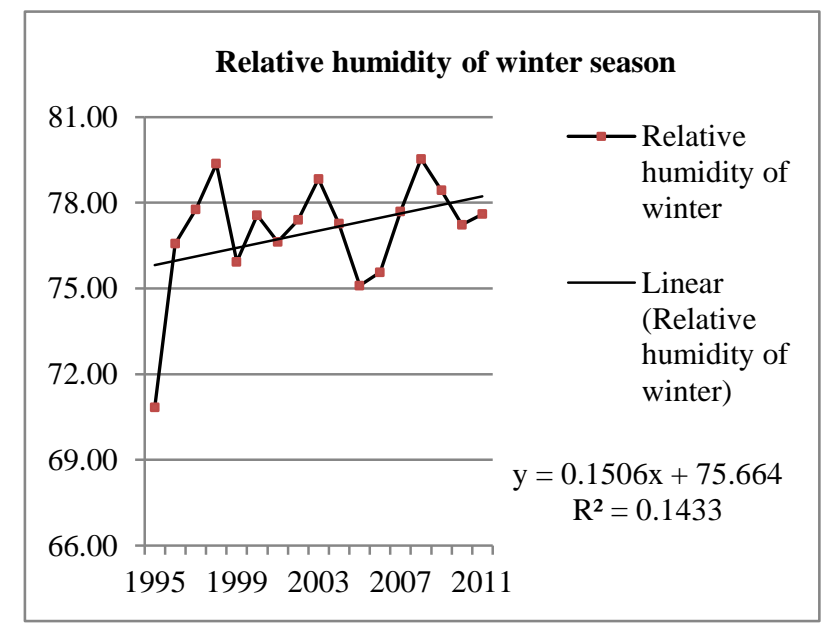

Figure 16: Relative humidity of winter season (Source: BMD, 2012) 


\subsection{Trend in Ground Water Level}

The ground water level of the study area is falling gradually due to huge pressure of irrigation and lower rainfall. From the Fig. 17, it can be observed that the ground water level from last decade falling drastically. At present the ground water level is about $16 \mathrm{~m}$ which was about $8 \mathrm{~m}$ in the year of 1995 .

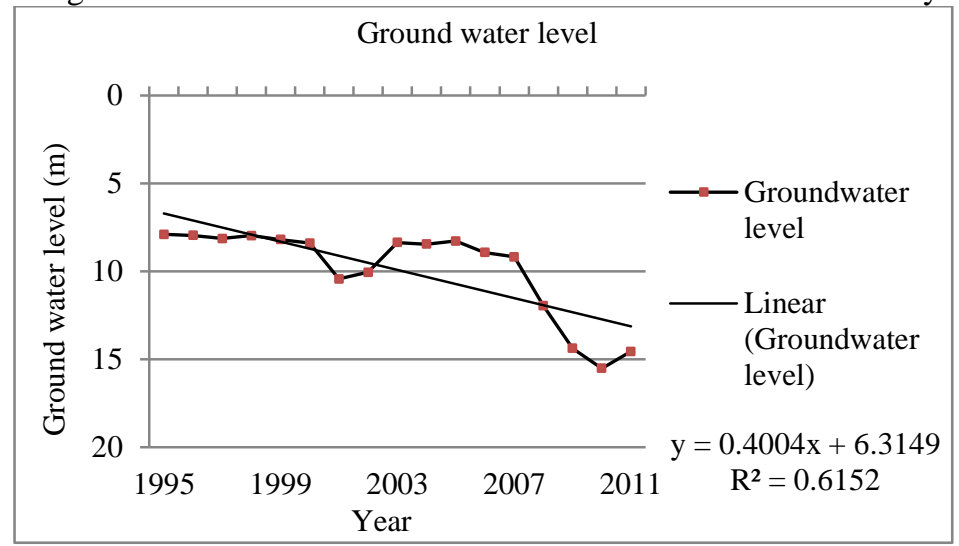

Figure 17: Ground water level (Source: BMDA, 2012)

The declining level of ground water is showing some irregularities in different season. In pre-monsoon (Fig. 18) and winter season (Fig. 21), the rate is higher due to the huge pressure of irrigation demand and lower rainfall. The monsoon (Fig.19) and post-monsoon (Fig. 20) season also showing declining trend of ground water level indicating that the recharge from the precipitation is not satisfactory.
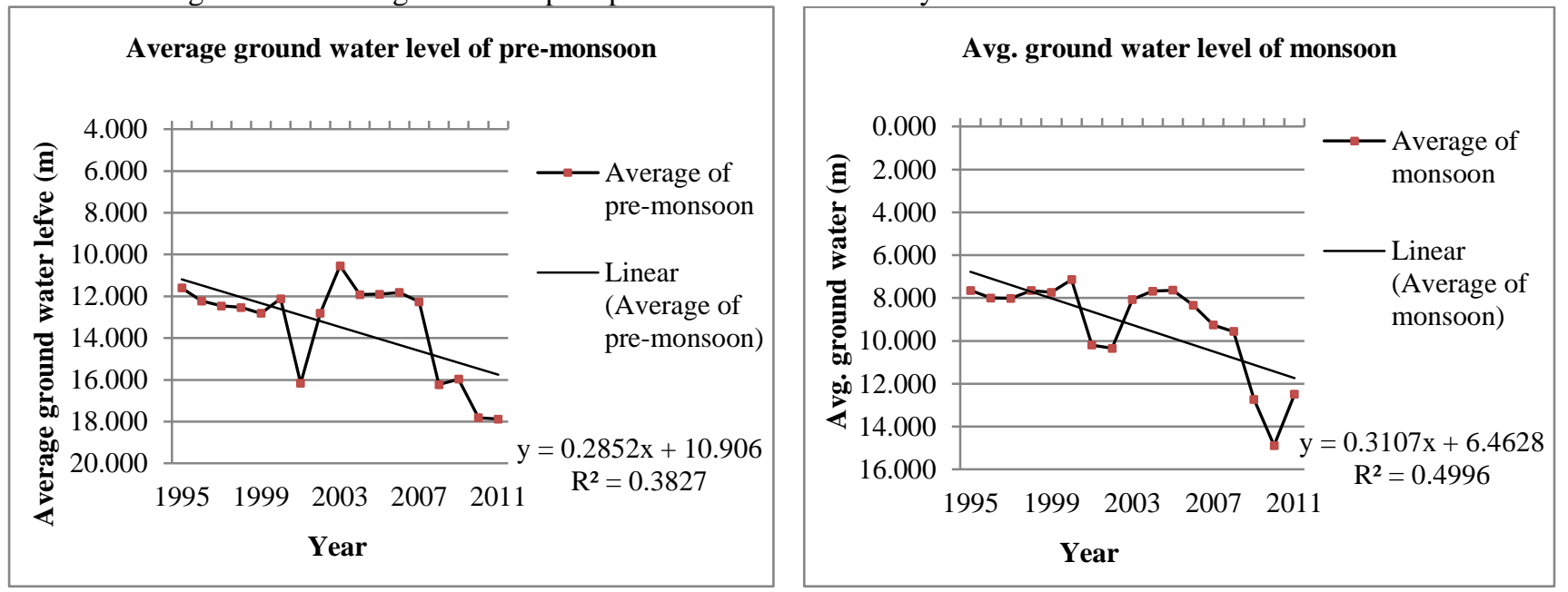

Figure 18: Avg. ground water level of pre-monsoon (Source: BMDA, 2012)

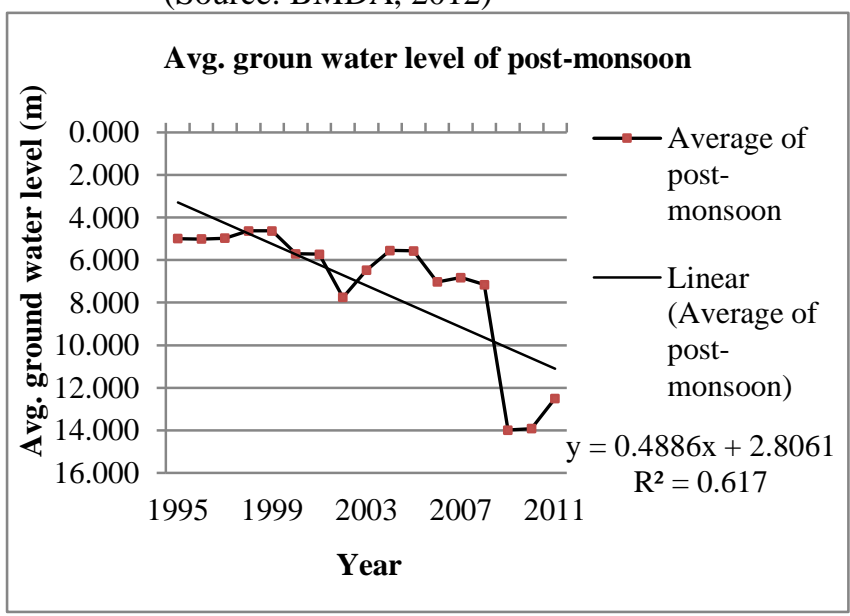

Figure 20: Avg. ground water level of post-monsoon (Source: BMDA, 2012)

Figure 19: Avg. ground water level of monsoon (Source: BMDA, 2012)

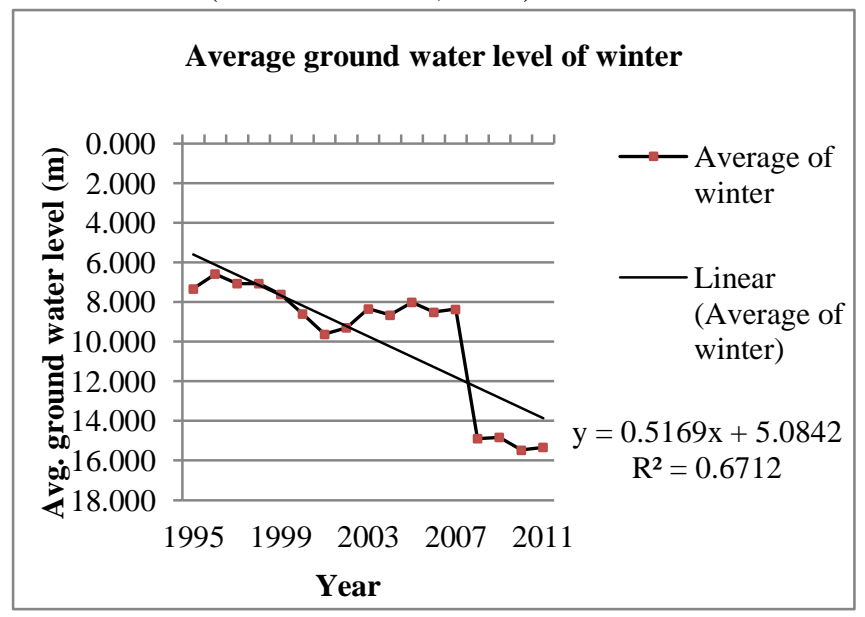

Figure 21: Avg. ground water level of winter (Source: BMDA, 2012) 


\section{3 Irrigation Development}

In the study area, the irrigation facility is totally depends on the ground water withdrawal. For the ground water abstraction Deep Tube Well (DTW) and Shallow Tube Well (STW) is used generally. Ground water abstraction through tube wells principally for irrigation is estimated from the number of irrigation unit and pumping hours. Fig. 22 shows the numbers of the shallow and deep tube well installed over the years in the study area. Fig. 23 shows the coverage of the tube wells which are also increasing as like the number of the tube well due to ensure increasing demand of supplementary irrigation. Irrigation water from the tube well is also increasing gradually. Fig. 24 shows that the irrigation water supply increased 4 times in the last fifteen years and which is one of the major reason for the ground water depletion.

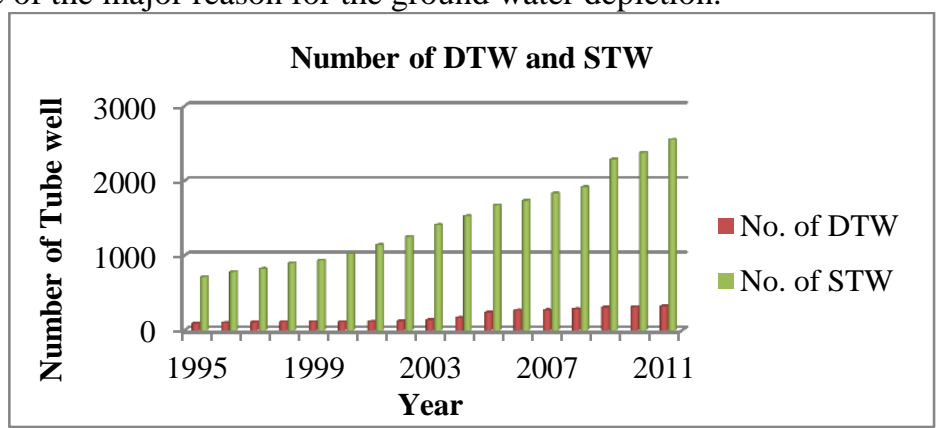

Figure 22: Number of tube well in the study area (Source: BMDA, 2012)

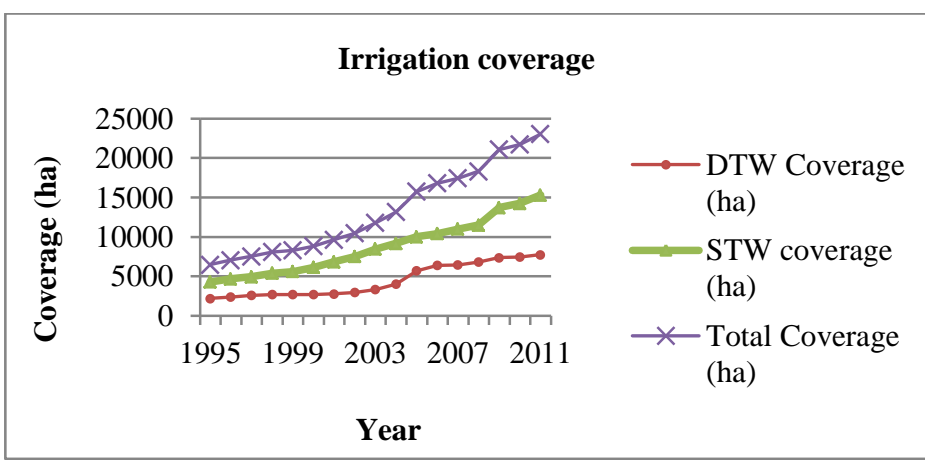

Figure 23: Irrigation coverage of the study area (Source: BMDA, 2012)

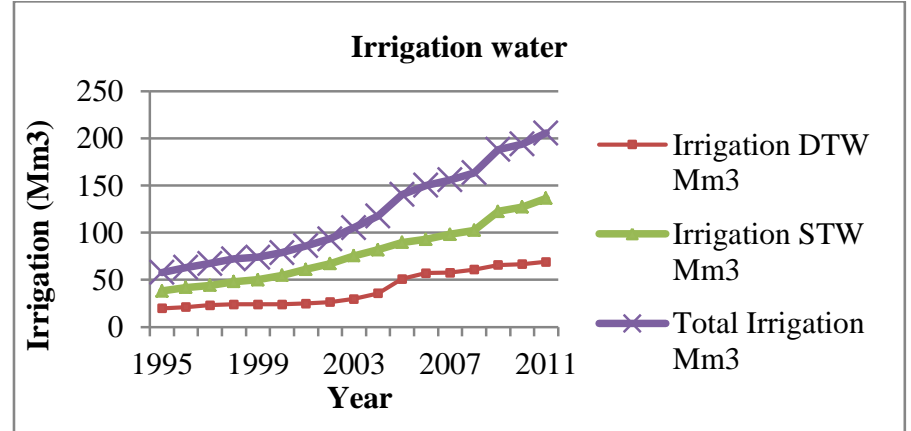

Figure 24: Irrigation water amount in the study area (Calculation 2012)

\subsection{Comparison of irrigation development and ground water level}

Irrigation development and the ground water level fluctuation are plotted in the fig. 25 . From the figure it can be observed that ground water level is depends on the irrigation development. And from the 2005, the irrigation development creates rapid ground water depletion as the irrigation increasing and cross the sustainable level. From fig 26, it can be observed that the ground water level and irrigation development has a strong correlation. 


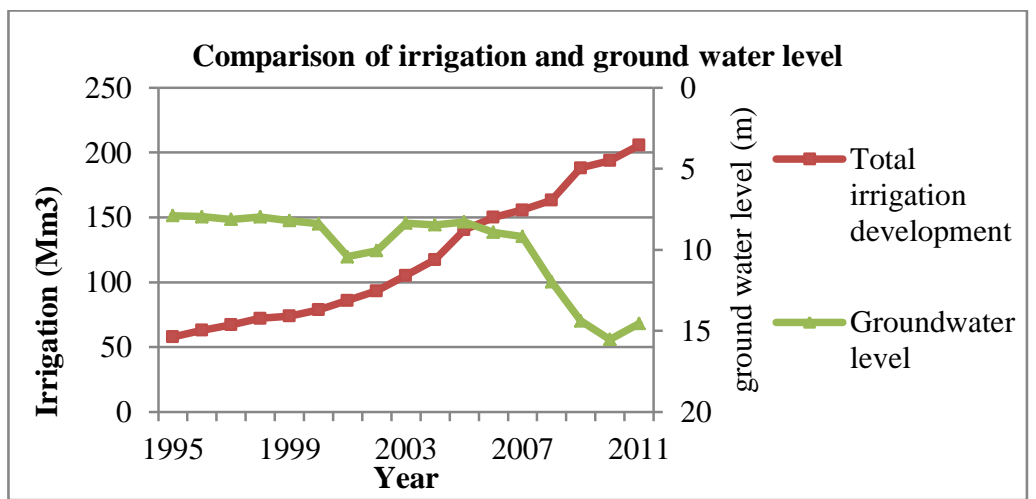

Figure 25: Comparison of the irrigation development and ground water level

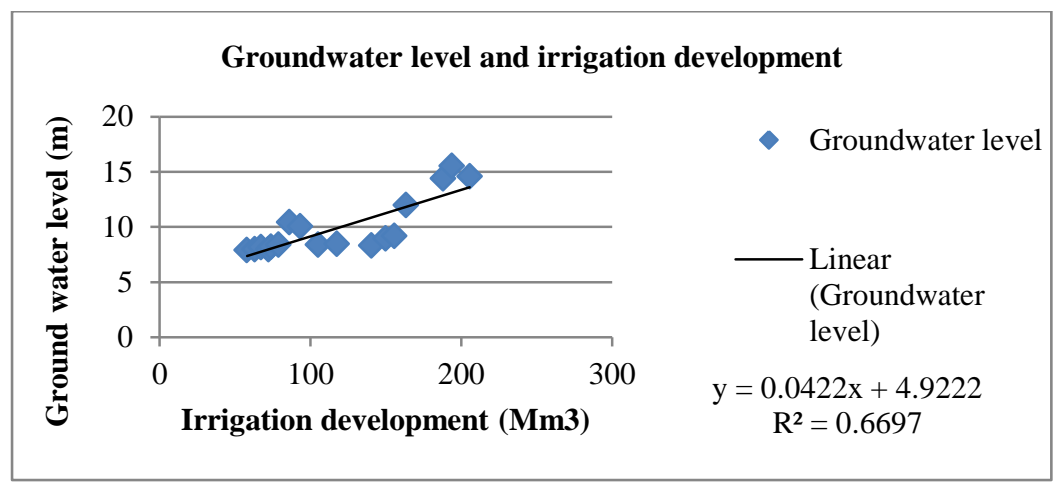

Figure 26: Correlation between ground water and irrigation development

\subsection{Correlation and Regression Analysis of the Climatic Variables and Crop Yield 3.5.1 Correlation analysis}

The correlation analysis is performed among the climatic variables and crop yield. The results are shows in Table 1

Table 1: The correlation analysis of climatic variables and crop yield

\begin{tabular}{|l|l|l|l|l|l|}
\hline Crop & Rainfall $(\mathbf{m m})$ & $\begin{array}{l}\text { Average } \\
\text { Temperature }\left({ }^{\mathbf{O}} \mathbf{C}\right)\end{array}$ & Relative humidity & Groundwater level & $\begin{array}{l}\text { Irrigation } \\
\mathbf{d e v e l o p m e n t} \\
\left(\mathbf{M m}^{\mathbf{3}}\right)\end{array}$ \\
\hline Aman & -.383 & .407 & -.060 & .200 & .652 \\
\hline Boro &. .020 & .171 & .211 & .726 & .877 \\
\hline Aus & .446 & -.295 & .340 & .226 & .895 \\
\hline Wheat & -.077 & & .585 & .838 \\
\hline
\end{tabular}

The correlation analysis revealed the correlation between climatic variables (for the period of growth of crops under study) with ground water level and irrigation development and crop yields. From the table, rainfall is positively correlated with aus (0.446), but negatively correlated with aman (-.383), boro (-.020) and wheat (.077). The implication of this is high rainfall is favorable for the aus production. However, aman is also depends on the monsoon rainfall but for the good production of aman extensive rainfall is not required rather regular rainfall is important. Besides in the winter rainfall is almost not occurring in the study area and production is totally depends on the supplementary irrigation.

Temperature has a positive weak correlation with the aman (.407) and Aus (.171) whereas a negative correlation with the boro (-.060) and (-.295). This result indicates that high temperature is negatively affected on the boro and wheat production as high temperature increase the water demand.

The relative humidity has positive but weak correlation with the aman (.200), boro (.442), aus (.211) and wheat (.340). This result indicates that high relative humidity is helpful for the high production of crops as its high relative humidity influence the plant development and photosynthesis of the leaves.

The ground water level has a strong correlation with the aman (.726), boro (.877) and wheat (.875) whereas has a positive but weak correlation with aus (.226) production. This result indicates that the crop production in this area is totally depends on the ground water irrigation supply and this dependency is height in case of boro and wheat due to the lack of rainfall in the winter time.

The irrigation development has a strong correlation with the crops as the production of this region is fully depends on the irrigation supply. The irrigation development has a strong correlation with boro (.895) and 
wheat (.838), those are the winter crops and solely depends on the supplementary irrigation. Besides it has a significant correlation with the aman (.652) and aus (.585) indicates that all the crops of this area required supplementary irrigation due to the irregular and law rainfall.

\subsubsection{Regression analysis}

The regression analysis is also performed among the climatic variables and crop yield. List of variables used in regression model construction are

\begin{tabular}{|l|l|}
\hline Dependent variables & Independent variables \\
\hline Aman paddy & Rainfall \\
Aus paddy & Temperature \\
Boropady & Relative humidity \\
Wheat & Ground water level \\
& Irrigation development \\
\hline
\end{tabular}

Table 2: Result of multiple regression analysis between climate and others variable with the crop yield in the study area

\begin{tabular}{|l|l|l|l|l|}
\hline Crops & $\mathrm{R}^{2}$ & $\mathrm{R}^{2}$ (Adjusted) & F value & P value \\
\hline Aman & .922 & .667 & 26.064 & .000 \\
\hline Aus & .416 & .151 & 1.570 & .247 \\
\hline Boro & .908 & .866 & 21.594 & .000 \\
\hline Wheat & .829 & .752 & 10.698 & .001 \\
\hline
\end{tabular}

The regression analysis computed for the crops revealed that aman, aus, boro and wheat have coefficient of determination of $0.92,0.42,0.90$, and 0.82 , respectively. This indicates that 92, 42, 90, and $82 \%$ of the variance in aman, aus, boro and wheat respectively, can be explained by the independent parameters of the model under study (Table 2 ). The implication is that $08,58,10$ and $18 \%$ of the variance in aman, aus, boro and wheat can be, respectively explained by other factors not included in the study. Climatic variables and the other two factors therefore, have impact on selected crop yield over the years under study except for aus paddy with low percentage. From the $\mathrm{R}^{2}$ value it can be said that the crops yield values are laying closely in a straight line and and showing a trend except the aus paddy, which is moderately scattered and lower fit in the trend.

From the $\mathrm{P}$ value we can conclude that in aman, boro and wheat production there is a significant linear relationship between the dependent and independent variables as the $\mathrm{p}$ value is less than .05 . However, from the $\mathrm{P}$ value of aus production we can conclude that there is no significant relationship with the dependent variable.

\subsection{Farmer's Perception}

\subsubsection{Farmer's perception on the production trend}

Agricultural yield mainly depends on various factors, among them climate and technological advancement are the most influential. Technological advancement including High Yield Varieties, Pesticides, fertilizer, advanced agricultural tools, irrigation facilities etc increase the production. Climate also plays a very important role in the crop production. If the favorable climatic condition is not provided to the crops, then the production will be hampered. So, the climatic variation will adversely affect the yielding capacity of the agriculture.

In the study area, farmers (87\%) stated that the overall production of the crops is increasing. However, around $41 \%$ farmers responded that due to the technological advancement and more agriculture input, the production is increasing. On the other side, $46 \%$ farmers said that production is increasing but climatic variation creating considerable obstacles in this process and hampering the production in a large extent. Besides, $8 \%$ farmers said that the production was decreasing while 5\% farmers argued that it's remained same.

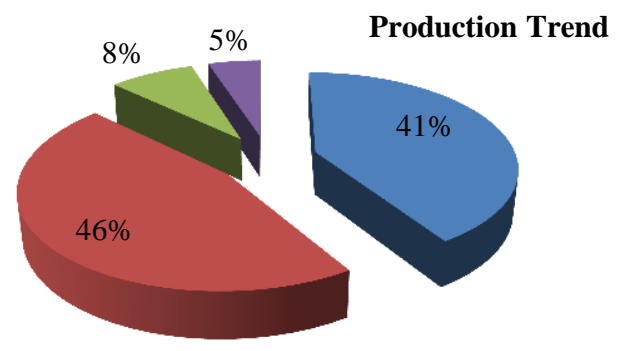

\footnotetext{
- Increasing due to more agri. Input and technological improvement

Increasing but climatic variation hampered

Decreasing due to the climatic variation

Production remain same
}

Figure 27: Farmers view on production trend (Source: Field Survey, 2012) 
In the study area, farmers $(46 \%)$ responded that due to the climatic variation the production has been hampered and another $8 \%$ farmers believe that due to the climatic variations the total production is decreasing day by day. They also identified the major reasons responsible for the adverse impact of the production.

Among the different reasons for production loss, majority of farmers responded that temperature increase and monsoonal change are very harmful for them followed by erratic rainfall. Along with these reasons they argued that prolonged dry spell and lower rainfall in winter is also responsible for the lower production. Moreover farmers identified short winter season, winter season intensity increase, excessive fogging etc. are also responsible for hampering the crop production.

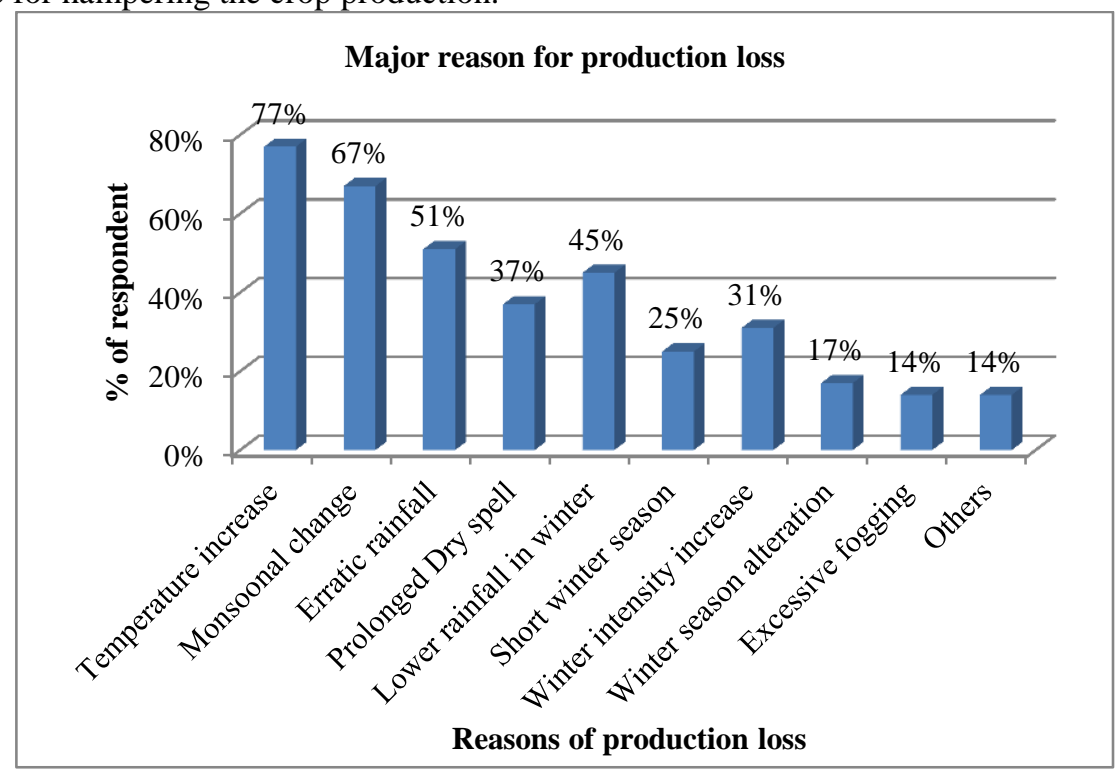

Figure 28: Farmers perception on the production loss (Source: Field Survey, 2012)

\subsection{Existing adaptation measure}

In the study area, local farmers adopted some feasible options to cope with the climatic variability by using their indigenous knowledge considering their economic capacity. However, these options are very few in compare to the problem. Local farmers responded that they have changed their plantation time due to the seasonal variability. They are now transplanted aman and boro rice before June and January, respectively to ensure the rainfall. Moreover, farmers changed their cropping patter and more interested to selected water scarcity tolerant species especially wheat. Apart from this they are also converting their agricultural land into the mango garden as its not required supplementary irrigation. Local farmers are selecting different short duration and drought tolerant crop species to overcome the adverse climatic condition including short duration boro rice varieties-BRRI dhan36, short duration rice varieties during kharif season-BRRI dhan39, BRRI dhan33, drought tolerant rice varieties during kharif season-BRRI dhan42, BRRI dhan43 and low water requirement and short duration wheat varieties-Hashi.

For ensure the irrigation facilities, they are digging little pond, just besides their agricultural land and conserve the rain water. For the irrigation, the farmers of this area also set shallow tube well in the pond to reach in the water level for supply. Through the help of some organization, local farmers interlinked the little khals to water supply. For ensure the sustainable irrigation facility, local people using different tools to assess how much irrigation is required. Also they were using some local knowledge for water efficiency like set up some pot which supplies water in drop.

Table 3: Farmers perception on the existing adaptive measures

\begin{tabular}{|ll|c|}
\hline \multicolumn{2}{|l|}{ Adaptive Measures } & No. of Respondent (\%) \\
\hline 1. & Change of transplantation time & $64 \%$ \\
\hline 2. & Cropping pattern change & $55 \%$ \\
\hline 3. & Setup shallow tube well in pond & $41 \%$ \\
\hline 4. & Short duration species selection & $35 \%$ \\
\hline 5. & Little pond digging to conserve rain water & $29 \%$ \\
\hline 6. & Interlinked with little khal & $21 \%$ \\
\hline 7. & Improved irrigation facility & $18 \%$ \\
\hline \multicolumn{2}{|l}{} \\
\hline
\end{tabular}

Source: Field Survey, 2012 


\section{Conclusion}

The climatic variables including temperature, rainfall and relative humidity are showing a variation in the study area which has huge impact on the agriculture production. Although the production rate of the study area is increasing but farmers said that it's required more agriculture input currently which ultimately reduces their economic gain. The result of time series analysis shows that the average temperature increasing in a trend rate of $0.030{ }^{\circ} \mathrm{C} / \mathrm{yr}$. The temperature pattern of different season is also showing positive trend. The rainfall pattern is showing irregularities and decreasing in a gradual trend. The seasonal rainfall also shows a decreasing trend and all the rainfall distributions are mainly in the monsoon period whereas the rainfall in the winter season nearly zero which affect on huge pressure on the ground water based irrigation supply. The relative humidity also shows a positive trend in average and in all season except the post-monsoon indicates the dry condition. The ground water level is declining in a very fast rate because of irregular rainfall with huge pressure of ground water based irrigation. As the production level of the yield have some positive correlation with the ground water level, it's very important to concentrate on the efficient use the ground water. All these variability's aggravate the vulnerability of crop production. Local farmers also recognized different climatic variation including temperature increase, monsoonal change, erratic rainfall, lower rainfall in the winter, prolonged dry spell etc. which are also observed in the trend analysis of the climatic factors. Local farmers also identified different consequence on crop production due to the climatic variation. Most of the responded said that climatic variation hampered the production by restrict plant growth, delay transplantation, high viral and pest attack, root spoil, nutrient deficiency etc. Local people have adopted different coping mechanism to minimize the impact of climatic variation on crop production including change of transplantation time, cropping pattern change, digging small pond besides the land, short duration species etc. However they argued that more institutional initiative should be introduced to cope with these adverse climatic conditions.

\section{References}

[1]. Ahmed, A.U. and Alam, M.A., 1999, "Development of Climate Change Scenarios with General Circulation Models", In Vulnerability and Adaptation to Climate Change for Bangladesh. S. Huq, Z. Karim, M. Asaduzzaman and F. Mahtab (Eds.), 13-20.

[2]. Lai, M., Whettori, PH., Pittodi, A.B., and Chakraborty, B., 1998, "The greenhouse gas induced climate change over the Indian Subcontinent as projected by GCM model experiments." Terrestrial. Atmospheric and Oceanic Sciences, TAO, 9(iv): 663-669.

[3]. IPCC, 2007. Climate change 2007: climate change impacts, adaptation and vulnerability. Working Group II contribution to the Intergovernmental Panel on Climate Change Fourth Assessment Report. Summary for policymakers, 23pp.

[4]. Karim, Z., Hussain, Sk.G. and Ahmed, A.U., 1998, "Climate Change Vulnerability of Crop Agriculture", in S. Huq, Z. Karim, M. Asaduzzaman and F. Mahtab (Eds.), Vulnerability and Adaptation to Climate Change for Bangladesh, Kluwer Academic Publishers, Dordrecht. pp 39-54.

[5]. Huq, S., Z. Karim, M. Asaduzzaman and F. Mahtab (Eds.), 1996. Vulnerability and Adaptation to Climate Change for Bangladesh, Kluwer Academic Publishers, Dordrecht, pp. 135

[6]. Shafie, H., Shantana, R.H., Rashid, A.K.M., Lisa, K.S., Mita, H.A., 2007, Endowed wisdom: knowledge of nature and coping with disaster in Bangladesh. Dhaka: Comprehensive Disaster Management Programme (CDMP), Disaster Management and Relief Bhaban.

[7]. ADB (Asian Development Bank), 2005. Country strategy and program 2006-2010. Dhaka, Bangladesh: Bangladesh Resident Mission; 2005

[8]. Shahid. S. and Behrawan, H. 2010. Drought risk assessment in the western part of Bangladesh. Journal of the International Society for the Prevention and Mitigation of Natural Hazards 2008;46:391-413.

[9]. Paul, B.K., 1995, Coping mechanisms practiced by drought victims (1994/95) in North Bengal, Bangladesh. Applied Geography 1998;18:355-73

[10]. BBS (Bangladesh Bureau of Statistics) 2001, Bangladesh Population Census, Community Series, Naogaon, Bangladesh.

[11]. CEGIS \& FAO, 2006. Study on livelihood systems assessment, vulnerable groups profiling and livelihood adaptation to climate hazard and long term climate change in drought prone areas of NW Bangladesh. Improved Adaptive Capacity to Climate Change for Sustainable Livelihood in the Agriculture Sector.[BGD/01/004/01/99 DP/9/1]. Comprehensive Disaster Management Programme (CDMP). March 2006.

[12]. Kothari, C.R., 2006. Research Methodology, $2^{\text {nd }}$ Edition, New Age International (P) Ltd., New Delhi, India.

[13]. Banglapedia 2006, Rainfall in Bangladesh, National encyclopedia of Bangladesh. Asiatic Society of Bangladesh. 